\title{
Factors that Influence the Yield and Composition of Brazilian Propolis Extracts
}

\author{
Ildenize B. S. Cunha ${ }^{*, a}$, Alexandra C. H. F. Sawaya ${ }^{a}$, Fabio M. Caetano ${ }^{b}$, Mario T. Shimizu ${ }^{a}$, \\ Maria C. Marcucci ${ }^{c}$, Flavia T. Drezza ${ }^{a}$, Giovanna S. Povia ${ }^{a}$ and Patricia de O. Carvalho ${ }^{a}$ \\ ${ }^{a}$ Unidade Acadêmica da Área de Ciências Biológicas e da Saúde, Universidade São Francisco, \\ Av. São Francisco de Assis, 218, 12916-390 Bragança Paulista - SP, Brazil \\ ${ }^{b}$ Instituto de Ciências Biológicas e da Saúde, Centro Universitário do Sul de Minas, UNIS, \\ 37002-090 Varginha - MG, Brazil \\ ${ }^{c}$ Núcleo de Pós-Graduação, Pesquisa e Extensão, Universidade Bandeirante de São Paulo, \\ Rua Maria Candida, 1813, 02071-013 São Paulo - SP, Brazil
}

\begin{abstract}
Durante a extração de própolis foram variados alguns fatores para determinar como eles afetam o rendimento e o teor de fenóis totais. Seis amostras diferentes da região sudeste do Brasil foram testadas. Os resultados indicam que os maiores rendimentos de extratos de própolis obtidos por maceração, que também apresentam o maior número de componentes, foram aqueles usando $70 \%$ (v/v) ou maior proporção de etanol no solvente. A extração em Soxhlet resultou em um maior rendimento. Não foram observadas diferenças entre extratos de macerações com ou sem luz. Um aumento no rendimento da extração foi observado entre os extratos obtidos por maceração durante 10 e 30 dias, porém o teor de fenóis não variou significativamente nesses extratos. O teor de fenóis totais de todos os extratos variou entre 6,41 e 15,24\% mas nenhuma correlação direta foi encontrada com qualquer um dos fatores testados.
\end{abstract}

During the extraction of propolis several factors were varied in order to determine how they affected the yield and phenolic composition of the obtained extracts. Six samples of green propolis from the Southeastern region of Brazil were tested. The results indicate that the highest yield of propolis extracts obtained by maceration, which also had the greatest number of components, were those using $70 \%(\mathrm{v} / \mathrm{v})$ ethanol or more as a solvent. The Soxhlet extraction procedure resulted in even higher yields. No differences were observed between extracts macerated in the presence or absence of light. An increase in yield was observed between extracts macerated for 10 and 30 days although the phenolic content did not vary significantly. The total phenolic content of all extracts varied from 6.41 to $15.24 \%$ but no direct correlation could be found between any of the factors tested.

Keywords: propolis, extraction techniques, high performance liquid chromatography

\section{Introduction}

Propolis, a resinous substance collected by bees from plants around the hive, is masticated by the bees, salivary enzymes and beeswax added, then applied to the combs and walls of the hive, ${ }^{1}$ thereby insulating and reinforcing the hives as well as making the environment aseptic. For beekeepers, propolis is a by-product obtained by scraping the walls of the hives. Crude propolis is composed basically of $55 \%$ vegetable resins and balsam, $30 \%$ bee wax, $10 \%$ essential oil and $5 \%$ pollen. $^{2}$

* e-mail: ildenize@ saofrancisco.edu.br
Due to its antibiotic and anti-fungal activity, propolis has been used in folk medicine for many centuries ${ }^{3}$ and is presently used in health food and various pharmaceutical and cosmetic products such as mouthwash preparations, face creams, lotions and tablets. ${ }^{1}$ Traditionally, the fraction soluble in $70 \%$ ethanol was extracted and referred to as propolis balsam. ${ }^{3}$ In order to avoid the characteristic ethanolic smell and solubility problems of this product, propolis extracts using water ${ }^{4}$ or other solvents such as glycerol, edible oils and propylene glycol ${ }^{5}$ are presently found on the market. There is no standard either for extractive procedure or composition of products that contain propolis extracts. 
Researchers wishing to isolate specific substances from propolis will naturally use different solvents and extractive procedures, ${ }^{6}$ but when the extracts are supposed to be representative of the general composition of propolis, the extraction procedures used should be standardized. This is not what has been observed in literature. References have been found to extractive procedures using temperatures ranging from room temperature to $70{ }^{\circ} \mathrm{C}$, ethanolic concentrations between $60 \%$ and absolute ethanol and extractions lasting from 30 minutes to 10 days., ${ }^{5,-12}$

The purpose of this paper was to observe in which way several factors, which are commonly varied during commercial and research extractive procedures, affect the yield and phenolic composition of the propolis extracts. High Performance Liquid Chromatography (HPLC) analysis of selected extracts was performed, but cannot be expected to be used as a routine analytical procedure by beekeepers for reasons of cost. The standardization of the extractive procedures is the first step towards the implementation of quality control of propolis and propolis derived products.

\section{Experimental}

\section{Propolis samples}

The following samples of propolis were obtained from Apis mellifera beehives from the Southeastern region of Brazil.

\begin{tabular}{clll}
\hline Sample no. & Origin & Vegetation & Collection date \\
\hline 1 & Tuiuti, SP & $\begin{array}{l}\text { mixed native, } \\
\text { eucalyptus and } \\
\text { orange } \\
\text { mixed native, } \\
\text { eucalyptus and } \\
\text { orange } \\
\text { mixed native, } \\
\text { eucalyptus and }\end{array}$ & October 1998 \\
olive \\
mixed native \\
Tuiuti, SP
\end{tabular}

\section{Extraction procedures}

Maceration. Finely ground propolis was extracted by maceration at room temperature, with occasional shaking, in the proportion of $20 \mathrm{~g}$ of propolis to $100 \mathrm{~mL}$ of solvent. Extracts were obtained after 7, 10, 20 and 30 days of maceration, with and without light, and filtered. As solvents $100 \%$ absolute alcohol (Merck) was used and also diluted to $70 \%, 50 \%$ and $30 \%$ (v/v) with distilled water. Pure distilled water and commercial grain alcohol ( $\left.96^{\circ} \mathrm{GL}\right)$ were also employed.

Maceration with solvent renewal. Finely ground propolis was extracted by maceration at room temperature, with solvent renewal and occasional shaking, in the proportion of $20 \mathrm{~g}$ of propolis to $100 \mathrm{~mL}$ of solvent. Extracts were obtained after 30 days of maceration with grain alcohol ( $\left.96^{\circ} \mathrm{GL}\right)$, the solvent was renewed every 7 days.

Soxhlet. Finely ground propolis was extracted in a Soxhlet extractor for 24 hours at a maximum temperature of $60^{\circ} \mathrm{C}$, in the proportion of $20 \mathrm{~g}$ of propolis to $400 \mathrm{~mL}$ of absolute alcohol. In the case where distilled water was used as a solvent, in the same proportions, the temperature was of $100^{\circ} \mathrm{C}$.

Wax extraction. The extracts obtained through both Soxhlet and maceration procedures were left in a freezer overnight to induce the crystallization of dissolved waxes and then filtered at a temperature of approximately $0{ }^{\circ} \mathrm{C}$ to remove waxes from the extract. These waxes were not analyzed in the present study as their composition has already been studied by other Brazilian authors. ${ }^{13,14}$

\section{Analytical procedures}

Dry residue free of moisture and volatile substances. 10 $\mathrm{g}$ of finely ground propolis was heated to $100{ }^{\circ} \mathrm{C}$ for 5 hours, then desiccated until constant weight. The result is given as a percentage of the original weight of crude propolis.

Ash. The ash content of $2 \mathrm{~g}$ of finely ground crude propolis was determined by calcination at a temperature of $600{ }^{\circ} \mathrm{C}$ for 1 hour and then desiccated until constant weight. The ash content was calculated as a percentage of the weight of the dry residue.

Yield of the propolis extracts. All extracts, after wax extraction, were evaporated to dryness and weighed to obtain the yield. The results are given as a percentage of the original weight of crude propolis. The extracts obtained by ethanolic solutions are referred to as EEP (ethanolic extract of propolis), those obtained with distilled water as WEP (water extract of propolis).

Total phenolic content. The procedure used is based on the methods outlined by Folin-Ciocalteau ${ }^{15}$ and by the American Public Health Association. ${ }^{16}$ The method is based on an oxidation-reduction reaction in alkaline conditions, where the phenolate ion is oxidized while Folin's reagent is reduced, turning the solution blue. Many of the active components in propolis, such as phenolic acids and flavonoids, have a phenolic nucleus and can be evaluated by this method. A calibration curve was built using standard aqueous solutions of phenol containing between 2 and $12 \mu \mathrm{g} \mathrm{mL}^{-1}$. One $\mathrm{mL}$ of each solution was added to $250 \mu \mathrm{L}$ 
of sodium carbonate-tartarate buffer and $25 \mu \mathrm{L}$ of the Folin-Ciocalteau reagent in a test tube, homogenized and allowed to react for 30 minutes at a temperature of $20^{\circ} \mathrm{C}$. Absorbance was measured at $700 \mathrm{~nm}$ on a Beckman DE640 spectrophotometer and the calibration curve calculated by the minimal squares method. The dry extracts of propolis were dissolved in absolute alcohol to a concentration of $20 \%(\mathrm{~m} / \mathrm{v})$, one $\mathrm{mL}$ of this ethanolic solution was further diluted in $1000 \mathrm{~mL}$ of distilled water and homogenized. One $\mathrm{mL}$ of this final solution was prepared and analyzed in the same way as the standards. The results are given as a percentage of the dry extract in weight.

High Performance Liquid Chromatography. Analytical HPLC was run on HPLC (Merck-Hitachi, Germany), equipped with a pump (model L-7100, Merck-Hitachi, Germany) and a diode array detector (L-7455, MerckHitachi, Germany). Separation was achieved on a Lichrochart 125-4 column (Merck, Darmstadt, Germany) (RP-18, 12.5 × $0.4 \mathrm{~cm}, 5 \mu \mathrm{m}$ particle size) using water, formic acid $(95: 5, \mathrm{v} / \mathrm{v})$ (solvent A) and methanol (solvent B). All organic solvents were purchased from Merck (Darmstadt, Germany). The elution was carried out with a

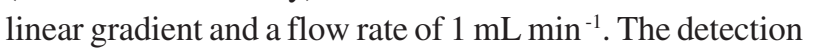
was monitored at 280 and $340 \mathrm{~nm}$ and the components identified by comparison with standards that were acquired commercially or previously isolated from other samples of Brazilian propolis. ${ }^{17}$ Components which presented the identical UV spectrum as standards but had different retention times from these were named as derivatives of these compounds (e.g. Kaempferol derivative 1).

\section{Results and Discussion}

All the samples of propolis analyzed were typical of green propolis from the Southeastern region of Brazil, derived from resins of Baccharis dracunculifolia. ${ }^{18}$ Although the six samples were collected during different months, over the period of one year, no variation was observed in the chemical composition ${ }^{19}$ nor in the antimicrobial activity ${ }^{20,21}$ of samples of propolis from the Southeast of Brazil collected in different seasons. Therefore, although it was expected that the same basic composition would be found in the six samples analyzed, the results of each sample have been reported separately and the results compared only within each sample, for the sake of precision.

\section{Crude propolis}

The dry residues and ash content of the samples (Table 1) are in accordance with the guidelines instituted by São Paulo State Beekeeper's Association ${ }^{22}$ which recommend a maximum ash content of 5\% (as adulteration of crude propolis with soil or other residues would be detected by this test) and maximum humidity of $8 \%$. As the dry residue represents the sample of crude propolis without moisture and volatile substances, it can be taken as a rough estimate of the moisture that was present in the crude propolis samples. The percentage of moisture in a sample of propolis is affected by the storage and manipulation conditions and should always be considered. Our results are similar to those obtained by Woisky and Salatino ${ }^{23}$ who reported ash content between $1.87 \%$ and $7.16 \%$ and dry residues between $90.2 \%$ and $94.2 \%$ for several samples from the South and Southeast of Brazil. Bonvehi et al. ${ }^{24}$ report ash content of $3.10 \%$ but very high moisture content $(22.60 \%)$ for a sample of Brazilian propolis.

Table 1. Dry residues and ash content of 6 samples of crude propolis from Southeastern Brazil

\begin{tabular}{ccc}
\hline Sample number & Dry residue $(\%)$ & Ash content $(\%)$ \\
\hline 1 & 93.2 & 4.07 \\
2 & 95.4 & 4.59 \\
3 & 91.3 & 3.80 \\
4 & 90.6 & 4.23 \\
5 & 92.2 & 2.55 \\
6 & 91.4 & 3.25 \\
\hline
\end{tabular}

Propolis extracts

Propolis sample 1. This sample was extracted using only absolute alcohol by Soxhlet and by maceration at room temperature for 10 and 20 days in order to observe how these procedures affected the yield and total phenolic content of the extracts (Table 2). The use of the Soxhlet resulted in higher yields. No significant difference was observed between the yield of samples macerated for 10 or 20 days, nor between the phenolic contents of the three extracts.

Table 2. EEP yield and phenolic content of propolis sample 1 extracted with absolute alcohol by Soxhlet and maceration

\begin{tabular}{lcc}
\hline Extraction procedure & $\begin{array}{c}\text { Yield of EEP } \\
(\%)\end{array}$ & $\begin{array}{c}\text { Phenolic content } \\
(\%)\end{array}$ \\
\hline Soxhlet & $57.65 \pm$ s.d. 1.96 & $13.34 \pm$ s.d. 1.32 \\
maceration 10 days & $38.23 \pm$ s.d. 2.35 & $11.50 \pm$ s.d. 3.62 \\
maceration 20 days & $40.43 \pm$ s.d. 0.72 & $11.87 \pm$ s.d. 1.37 \\
\hline
\end{tabular}

Propolis sample 2. This sample was extracted by maceration at room temperature for 20 days using the following 5 solvents: $100 \%$ absolute alcohol and diluted to $70 \%, 50 \%$ and $30 \%$ with distilled water, as well as grain alcohol $\left(96^{\circ} \mathrm{GL}\right)$; in the presence and absence of light. For comparison purposes, it was also extracted by Soxhlet with absolute alcohol. Once again the yield of EEP using the 
Soxhlet was greater than the corresponding maceration with absolute alcohol. For the maceration extraction procedure, the yield of EEP was proportional to the ethanolic concentration in the solvent, with a linear correlation coefficient of 0.88 . Extractions with or without light rendered practically the same results. The phenolic content of the extracts was approximately the same for both types of extractions and different solvents (Figure 1).
HPLC analysis of selected extracts (Table 3) shows the comparative compositions of EEP obtained by maceration with $50 \%$ and $70 \%$ ethanol. The results show that a greater number of compounds are present in the extraction using $70 \%$ ethanol, as well as an increase in the quantities of most of these components.

Propolis sample 3. This sample was extracted by maceration with the same solvents as sample 2 in order to

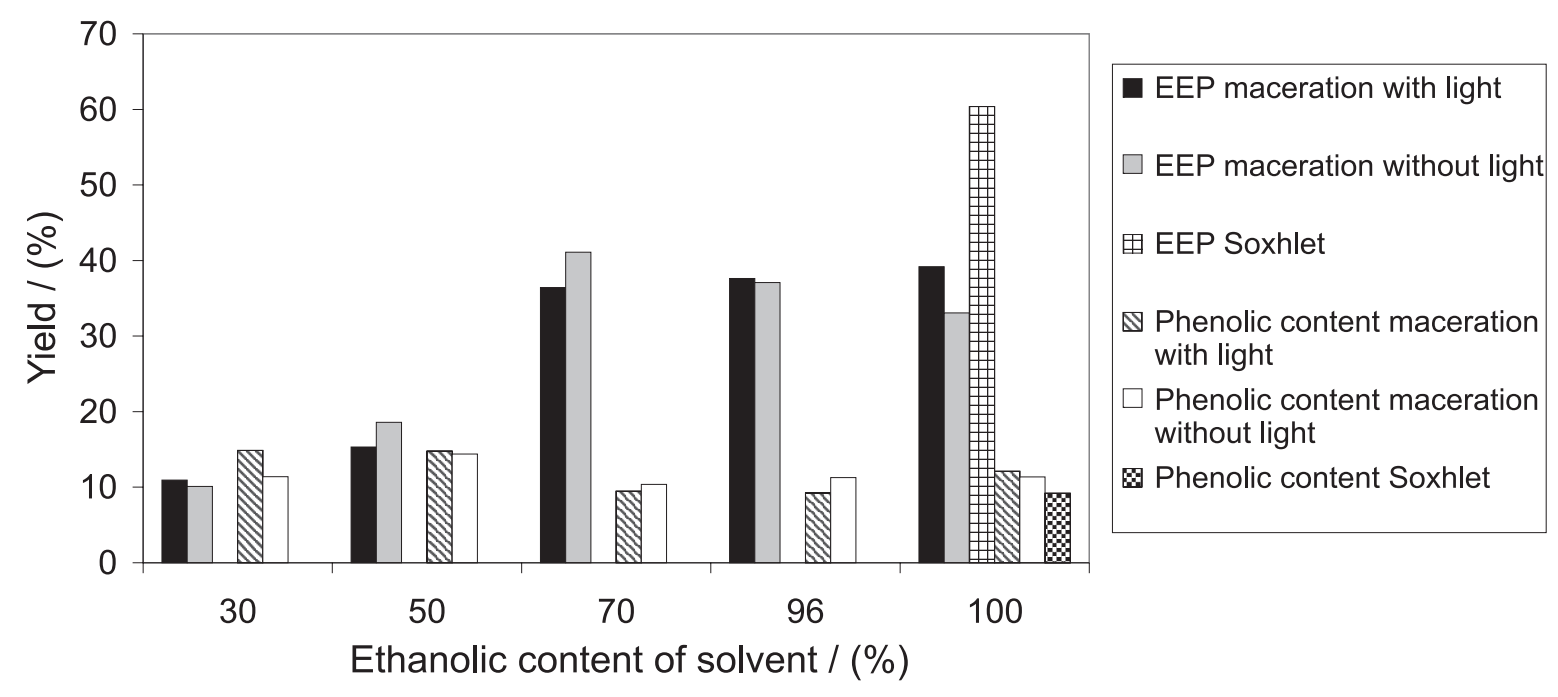

Figure 1. EEP yield and phenolic content of propolis sample 2 extracted with several solvents, by Soxhlet and maceration with and without light for 20 days.

Table 3. Composition and quantification by HPLC of selected extracts obtained by maceration with different solvents of propolis samples 2 and 3 , results in $\mathrm{mg} \mathrm{g}^{-1}$ dry extract

\begin{tabular}{|c|c|c|c|c|c|}
\hline \multirow[b]{2}{*}{ COMPOUND } & \multicolumn{2}{|c|}{ SAMPLE 2} & \multicolumn{3}{|c|}{ SAMPLE 3} \\
\hline & $50 \%$ Ethanol & $70 \%$ Ethanol & $30 \%$ Ethanol & $50 \%$ Ethanol & $70 \%$ Ethanol \\
\hline Caffeic acid & 0.27 & 1.00 & 0.55 & 1.10 & 0.63 \\
\hline p-Coumaric acid & 3.91 & 11.24 & 9.57 & 22.27 & 15.61 \\
\hline Ferulic acid & 0.26 & 0.80 & 1.32 & 2.76 & 0.63 \\
\hline Dicaffeoylquinic acid isomer 1 & 1.71 & 2.99 & & & \\
\hline 3,5-Diprenyl-4-hydroxycinnamic acid derivative 1 & 1.37 & 1.00 & & 0.91 & 0.41 \\
\hline Pinobanksin & & 12.99 & & & 14.34 \\
\hline Dicaffeoylquinic acid isomer 2 & 2.01 & 0.45 & & & \\
\hline 3,5-Diprenyl-4-hydroxycinnamic acid derivative 2 & 0.23 & 1.64 & & 0.82 & 0.52 \\
\hline 3,5-Diprenyl-4-hydroxycinnamic acid derivative 3 & & 1.22 & & 0.59 & 0.44 \\
\hline 3-Prenyl-4-hydroxycinnamic acid & 7.36 & 16.88 & 1.54 & 9.47 & 14.68 \\
\hline 3,5-Diprenyl-4-hydroxycinnamic acid derivative 4 & & 0.94 & & 0.34 & 1.27 \\
\hline 2,2-Dimethyl-6-carboxyethenyl-2H-1-benzopyran & 0.69 & 1.58 & & 1.26 & 2.21 \\
\hline 3,5-Diprenyl-4-hydroxycinnamic acid derivative 5 & & 0.60 & & 1.39 & 0.81 \\
\hline Kaempferol derivative 1 & 3.98 & 14.16 & & 7.17 & 11.16 \\
\hline 3,5-Diprenyl-4-hydroxycinnamic acid derivative 6 & & 4.04 & & & 1.50 \\
\hline Cinnamic acid derivative 1 & & 4.09 & & & \\
\hline 3,5-Diprenyl-4-hydroxycinnamic acid derivative 7 & & 4.66 & & & 0.55 \\
\hline 3,5-Diprenyl-4-hydroxycinnamic acid derivative 8 & & & & & 1.66 \\
\hline 3,5-Diprenyl-4-hydroxycinnamic acid derivative 9 & & & & & 0.67 \\
\hline 3,5-Diprenyl-4-hydroxycinnamic acid & 7.55 & 31.66 & 1.54 & 9.20 & 31.99 \\
\hline 3-Prenyl-4-dihydrocinnamoyloxycinnamic acid & 2.63 & 18.93 & & 4.96 & 34.86 \\
\hline 2,2-Dimethyl-8-prenyl-2H-1-benzopyran-6-propenoic acid & 4.67 & 20.16 & & 3.47 & 14.00 \\
\hline TOTAL & 36.64 & 150.99 & 23.75 & 84.19 & 151.95 \\
\hline
\end{tabular}


see if the same linearity could be observed after only 10 days. The results (Figure 2) are similar to those observed for sample 2, with a linear correlation coefficient of 0.84 between solvent and yield of EEP. The presence or absence of light did not affect the yield of EEP and the phenolic content was similar for all the solvents tested. The composition of this sample and its antimicrobial activity is discussed in a previous paper. ${ }^{25}$ The highest yields were obtained using solvents containing $70 \%$ ethanol or more. In spite of being macerated for only 10 days, the yield of EEP was, on the whole, greater than for sample 2, which was macerated for 20 days. This surprising result is probably due to the composition of sample 3 which had a slightly lower ash content than sample 2 (Table 1) and also lower wax content (data not included).

Some of these extracts were analyzed by HPLC (Table $3)$. As for sample 2, the composition of the extracts increased qualitatively in proportion to the ethanolic content of the solvent, as well as the relative concentration of most of the components, which is in agreement with the yield of EEP. Of the phenolic compounds identified in the propolis extracts of samples 2 and 3, several have been mentioned in other papers studying the antibiotic, ${ }^{17,}{ }^{24-26}$ antioxidant, ${ }^{27}$ anti-inflammatory, ${ }^{28}$ cytotoxic $^{29}$ and antiparasitic $^{17}$ effects of Brazilian propolis.

Propolis sample 4. This sample was extracted only by maceration with absolute alcohol, in the absence of light, with constant shaking, for different periods of time $(10,20$ and 30 days), with several extractions for each period, in order to determine statistically how the length of time under maceration affected the yield and total phenolic content of the extracts. The results (Table 4) show that there was a significant increase in yield of EEP between 10 and 30 days, but not between 10 and 20 days, nor between 20 and 30 days. Although this increase was of approximately $10 \%$ (w/w) in relation to crude propolis, the phenolic content did not differ significantly between the periods tested. This is of importance for beekeepers who usually macerate propolis for over 30 days, with the objective of obtaining a better product, when they could put their product on the market in 10 days with practically the same yield and phenolic content.

Propolis sample 5. In order to widen the scope of the solvents employed, as well as to check the results obtained previously, this sample was extracted by maceration for 7 and 20 days with the same solvents as previously plus distilled water. The Soxhlet extractor was used with distilled water and absolute alcohol, for comparative purposes. The results for these extractions (Figure 3) are in accordance with those of the other samples; the Soxhlet resulted in higher yields of propolis extract for the solvents tested, there were practically no differences between extracts macerated for 7 and 20 days, the yield of extracts

Table 4. Average EEP yield and phenolic content of propolis sample 4 extracted for 10,20 and 30 days with absolute alcohol by maceration

\begin{tabular}{lcc}
\hline Extracted for & $\begin{array}{c}\text { Yield of EEP } \\
(\%)\end{array}$ & $\begin{array}{c}\text { Phenolic content } \\
(\%)\end{array}$ \\
\hline 10 days & $48.41 \pm$ s.d. $1.68^{\mathrm{a}}$ & $8.53 \pm$ s.d. 0.38 \\
20 days & $52.68 \pm$ s.d. 2.75 & $8.00 \pm$ s.d. 1.01 \\
30 days & $59.48 \pm$ s.d. $1.03^{\mathrm{a}}$ & $8.49 \pm$ s.d. 1.30 \\
\hline a Significant difference between results, $\mathrm{n}=6, \mathrm{p}=0.05$.
\end{tabular}

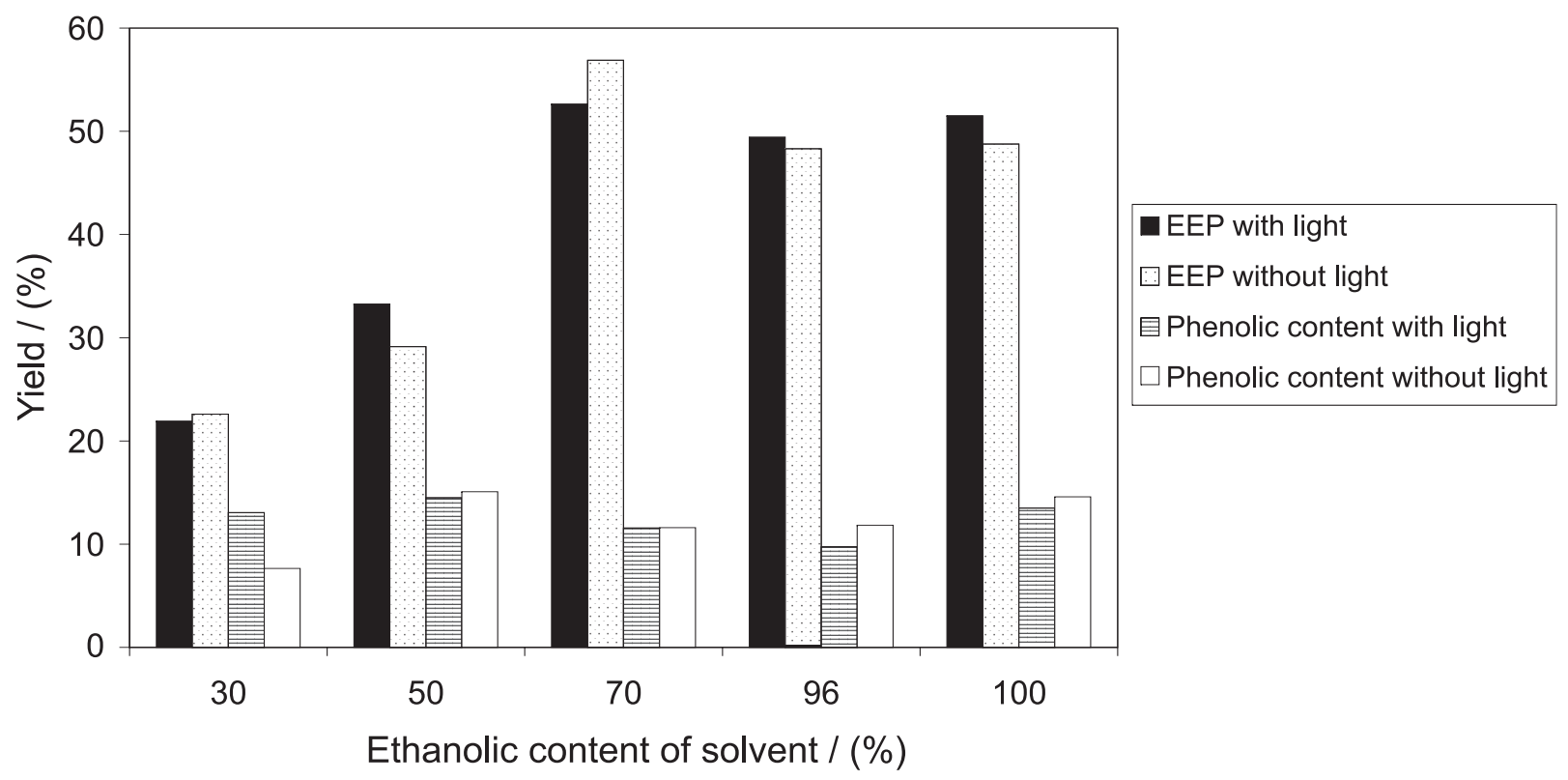

Figure 2. EEP yield and phenolic content of propolis sample 3 extracted with several solvents, by maceration with and without light for 10 days. 


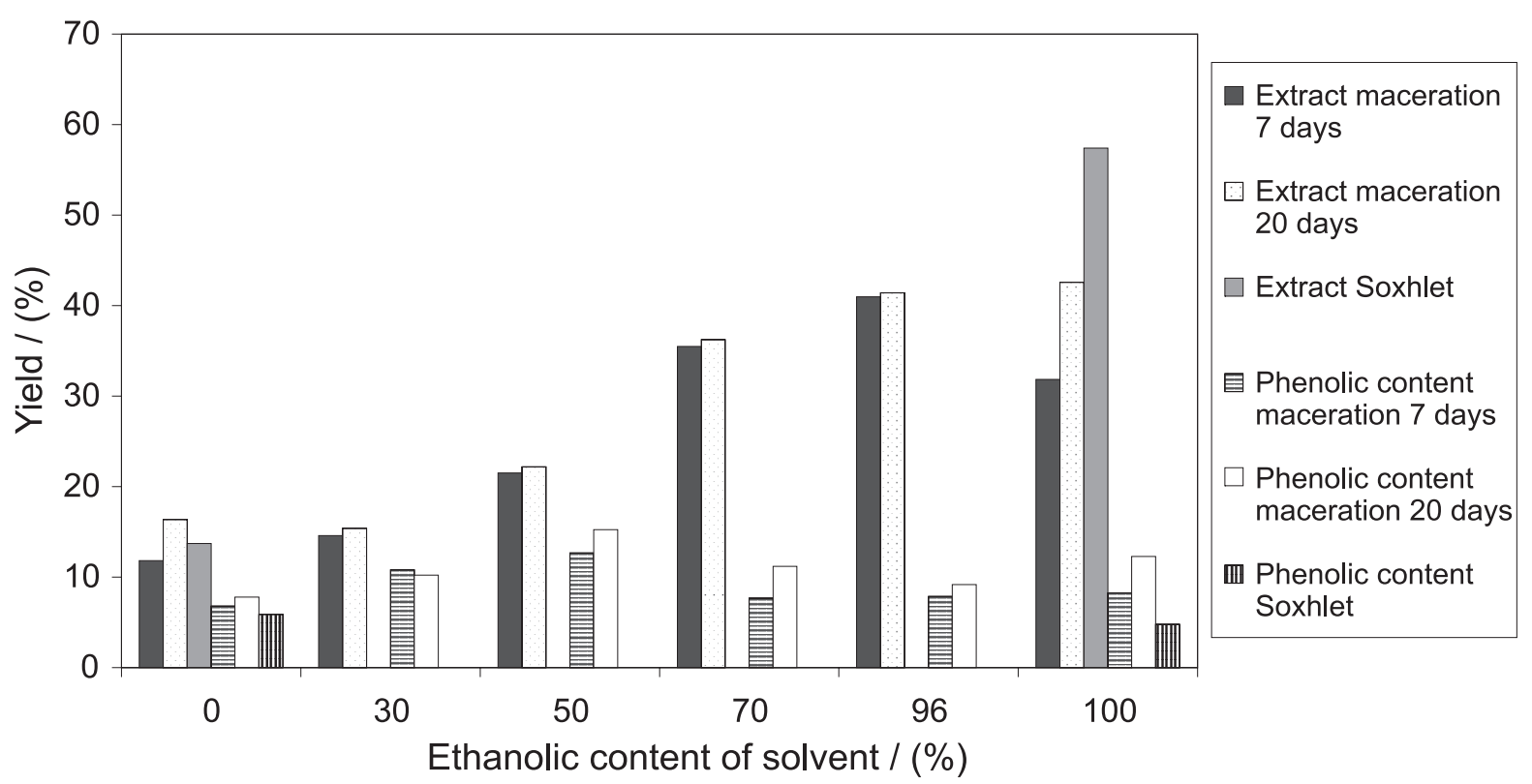

Figure 3. Extract yield and phenolic content of propolis sample 5 extracted with several solvents, by Soxhlet and maceration for 7 and 20 days.

was proportional to the ethanolic content of the solvent with a linear correlation coefficient of 0.92 for 7 days maceration and 0.94 for 20 days maceration. Although the phenolic content varied, this variation could not be correlated to any of the factors varied during the extraction. The yield of WEP was similar to that of EEP for 30\% ethanol indicating that both of these solvents extract mainly the same hydrophilic compounds.

Propolis sample 6. In order to observe the effect of the renewal of the solvent on the yield of propolis extracts, this sample was extracted using grain alcohol by maceration for 20 and 30 days and by maceration with solvent renewal for 30 days. The results (Table 5.) show that there was no difference in the yields of these three procedures, indicating that solvent saturation is not a limiting factor.

Table 5. EEP yield of propolis sample 6 extracted for 20 and 30 days with grain alcohol by maceration and for 30 days with grain alcohol by maceration with solvent renewal

\begin{tabular}{lc}
\hline Extracted for & Yield of EEP $(\%)$ \\
\hline 20 days & 62.52 \\
30 days & 59.50 \\
30 days with solvent renewal & 60.12 \\
\hline
\end{tabular}

\section{Comparison of extraction results with literature}

Of the hundreds of papers dealing with propolis, few authors have bothered to quantify the yield of extracts they were obtaining, with some noteworthy exceptions. Bonvehi et al. ${ }^{24}$ while studying the bacteriostatic activity of propolis, relate finding $47.60 \%(\mathrm{~m} / \mathrm{m})$ of resins and balsams and $10.10 \%$ of phenols (by spectrophotometry) in a sample of Brazilian propolis extracted with methanol. Nieva Moreno et al. ${ }^{11}$ report yields between 31 and $65 \%$ $(\mathrm{m} / \mathrm{m})$ for samples of Argentine propolis extracted with $80 \%$ ethanol. Miyataka et al. ${ }^{28}$ while studying the antiinflammatory effect of propolis, extracted several samples of Brazilian propolis with $99.5 \%$ ethanol and with distilled water, reporting yields of $41-60 \%(\mathrm{~m} / \mathrm{m})$ for the ethanolic extracts and of $4-14 \%(\mathrm{~m} / \mathrm{m})$ for the water extracts. In a similar procedure, Hayashi et al., ${ }^{27}$ studying the antioxidant effect of propolis, extracted a sample of Brazilian propolis with $70 \%$ ethanol and with distilled water, with a yield of $44.5 \%(\mathrm{~m} / \mathrm{m})$ for the ethanolic extract and of $11.1 \%(\mathrm{~m} / \mathrm{m})$ for the water extract. All the above results are in line with our own. The large variation of yield between different samples while using the same extractive procedure reflects the great variability of the composition of South American propolis.

Woisky and Salatino ${ }^{23}$ report a concentration of total phenolic substances between 8.8 and $13.7 \%(\mathrm{~m} / \mathrm{m})$ and a slight increase in the concentration of ethanolic tinctures extracted for 2, 7 and 30 days in relation to period of maceration; these findings are similar to ours. On the other hand they found that maceration with $70 \%$ ethanol resulted in $20 \%$ higher yields than with absolute alcohol. For our samples the yield of EEP using $70 \%$ ethanol or higher concentrations of ethanol was similar. They also reported that $70 \%$ ethanol did not extract waxes, whereas a certain percentage of wax was found in all the extracts obtained in this paper, even with solvents containing $50 \%$ or more of water (data not included). 
Park and Ikegaki ${ }^{30}$ extracted a sample of propolis from the state of Minas Gerais, Brazil, with mixtures of distilled water and ethanol containing from $0 \%$ to $95 \%$ ethanol. These authors did not measure the yield of EEP, but their results indicate that the highest percentage of the flavonoid pinocembrin, approximately $0.7 \%(\mathrm{~m} / \mathrm{m})$, was extracted with 60 to $80 \%$ ethanol. No other class of phenolic substances was reported.

\section{Conclusions}

The yield of propolis extract increased in proportion to the ethanolic content of the solvent, with this increase stabilizing using solvents with $70 \%$ ethanol or more. The use of the Soxhlet shortened the extraction time and increased the yield. No differences were observed between extracts macerated in the presence or absence of light in relation to yield, phenolic content or composition. Solvent renewal did not increase the yield of propolis extraction. Although there was an increase in yield between maceration for 10 and 30 days, the phenolic content of these extracts did not vary significantly. The total phenolic content of all extracts varied from 6.41 to $15.24 \%(\mathrm{~m} / \mathrm{m})$ but no direct correlation could be found to any of the factors varied. It is important to note, nevertheless, that the same phenolic content for an extract with a higher yield means a higher percentage of phenolic compounds extracted in relation to the sample of crude propolis.

\section{Acknowledgements}

Partial support for this work by FAPESP (Fundação de Amparo a Pesquisa do Estado de São Paulo) contracts no. 98/11719-4 and 95/09306-5 and Universidade São Francisco - PROPEP is gratefully acknowledged.

\section{References}

1. Burdock, G. A.; Food Chem. Toxicol. 1998, 36, 347.

2. Cizmarik, J.; Matel, I.; Experientia 1970, 26, 713.

3. Ghisalberti, E. L.; Bee World 1979, 60, 59.

4. Matsuno, T.; O Efeito Terapêutico da Própolis; Impressão Abaeté: São Paulo, 1997.

5. Tosi, B.; Donini, A.; Romagnoli, C.; Bruni, A.; Phytother. Res. 1996, 10, 335.

6. Pereira, A. S.; Pinto, A. C.; Cardoso, J. N.; Aquino Neto, F. R.; Ramos, M. F. S.; Dellamora-Ortiz, G. M.; Satos, E. P.; J. High Resol. Chromatogr. 1998, 21, 396.

7. Arvouet-Grand, A.; Vennat, B.; Pourrat, A; Legret, P.; J. Pharm. Belg. 1994, 49, 462.

8. Bankova, V.; Christov, R.; Kujumgiev, A.; Marcucci, M. C.; Popov, S.; Z. Naturforsch. 1995, 50 C, 167.
9. Bosio, K.; Avanzini, C.; D'avolio, A.; Ozino, O.; Savoia, D.; Lett. Appl. Microbiol. 2000, 31, 174.

10. Cizmarik, J.; Trupl, J.; Pharmazie 1975, 30, 406.

11. Nieva Moreno, M. I.; Isla, M. I.; Sampietro, A. R.; Vattuone, M. A.; J. Ethnopharmacol. 2000, 71, 109.

12. Park, Y. K.; Koo, M. H.; Sato, H. H.; Contado, J. L.; Arq. Biol. Technol. 1995, 38, 1253.

13. Negri, G.; Marcucci, M. C.; Salatino, A.; Salatino, M. L. F.; J. Braz. Chem. Soc. 2000, 11, 453.

14. Custodio, A. R.; Ferreira, M. M. C.; Negri, G.; Salatino, S.; J. Braz. Chem. Soc. 2002, 14, 354.

15. Folin, O.; Ciocalteau, V.; J. Biol. Chem. 1927, 27, 627.

16. American Public Health Association; Standard Methods for Examination of Water and Wastewater, $17^{\text {th }} \mathrm{ed}$, Washington, DC, 1989.

17. Marcucci, M. C.; Ferreres, F.; Garcia-Viguera, C.; Bankova, V. S.; de Castro, S. L.; Dantas, A. P.; Valente, P. H. M.; Paulino, N.; J. Ethnopharmacol. 2001, 74, 105.

18. Marcucci, M. C.; Ferreres, F.; Custódio, A. C.; Ferreira, M. M. C.; Bankova, V. S.; Garcia-Viguera, C.; Bretz, W. A.; Z. Naturforsch. 2000, 55C, 76.

19. Bankova, V.; Bourdourova-Krasteva, G.; Popov, S.; Sforcin, J. M.; Funari, S. R. C.; Apidologie 1998, 29, 361.

20. Sforcin, J. M.; Fernandes Jr., A.; Lopes, C. A. M.; Bankova, V.; Funari, S. R. C.; J. Ethnopharmacol. 2000, 73, 243.

21. Sforcin, J. M.; Fernandes Jr., A.; Lopes, C. A. M.; Funari, S. R. C.; Bankova, V.; J. Venom. Anim. Toxins 2001, 7, 63.

22. APACAME: São Paulo State Beekeeper's Association; Mensagem Doce 1999, 52, 12.

23. Woisky, R. G.; Salatino, A.; J. Apicult. Res. 1998, 37, 99.

24. Bonvehi, J. S.; Coll, F. V.; Jordà, R. E.; J. Am. Oil Chem. Soc. 1994, 71, 529.

25. Sawaya, A. C. H. F.; Palma, A. M.; Caetano, F. M.; Marcucci, M. C.; Cunha, I. B. S.; Araujo, C. E. P.; Shimizu, M. T.; Lett. Appl. Microbiol. 2002, 35, 203.

26. Aga, H.; Shibuya, T.; Sugimoto, T.; Kurimoto, M., Nakajima, S.; Biosci., Biotechnol., Biochem. 1994, 58, 945.

27. Hayashi, S.; Komura, S.; Isaji, N.; Ohishi, N.; Yagi, K.; Chem. Pharm. Bull. 1999, 47, 1521.

28. Miyataka, H.; Nishiki, M.; Matsumoto, H.; Fujimoto, T.; Matsuka, M.; Satoh, T.; Biol. Pharm. Bull. 1997, 20, 496.

29. Banksota, A. H.; Tezuka, Y.; Prassain, J. K.; Matsushige, K.; Saiki, I.; Kadota, S.; J. Nat. Prod. 1998, 61, 896.

30. Park, J. K.; Ikegaki, M.; Biosci., Biotechnol., Biochem. 1998, $68,230$.

Received: April 5, 2004

Published on the web: November 30, 2004

FAPESP helped in meeting the publication costs of this article. 